\title{
The Place of Language in (Re)constructing Identity: The Case of "Fortunate Immigrants" to/from Italy
}

\author{
Elizaveta Khachaturyan (University of Oslo, Norway) \\ Silvia Camilotti (University Ca' Foscari, Italy)
}

\begin{abstract}
Based on the analysis of the interviews (18 in total) conducted in Italy and in Norway, this article explores how identity is (re)constructed in a new host society, and it especially focuses on how the informants ("fortunate immigrants") define their national belonging and on the status the language has for them as a symbol or not of this belonging. It is argued that the sociocultural context and the relationship between participants in social interaction (such as an interview) affect the responses. The divergence that emerged from the responses can be interpreted as emphasizing the differences between a multilingual and monolingual society.
\end{abstract}

\section{Introduction}

Interest in the (re)construction of identity and the place of language in this process has been growing in recent decades. One of the reasons for this is the expansion of multilingualism and multiculturalism in society, especially due to the process of migration. The reasons for migration are often not only political or economic, but also personal: people may move to another economically and politically similar country because of a partner or because of new job opportunities. These types of immigrants have been called "fortunate immigrants" by Lindenfeld and Varro (2008). Scholars have shown that the status of "fortunate immigrants" and their behavior differ from other groups of immigrants. So far, this group of immigrants has rarely been studied separately, and their characteristics have not yet been clearly formulated (for a discussion, see Lindenfeld \& Varro 2008). "Fortunate immigrants" usually have a medium-high socio-economic status in their host society. This helps them maintain a stronger relationship with their country of origin. The study of "fortunate immigrants" as a particular case of migration can contribute to distinguishing different strategies in shaping and transmitting national belonging as well as to discovering possible transcultural differences. Moreover, such studies can help answer the more general question of how identities are (re)constructed in different countries.

This study uses interviews conducted in Italy and Norway to analyze how "fortunate immigrants" reconstruct their identity in these two countries and to explore what place language and other elements have in this reconstruction. These interviews are part of a 
longitudinal study, the main goal of which is a comparative study of the role of various aspects of national belonging (especially language) in shaping identity. In the article that follows we first explain the theoretical background that we used for this study, the various levels of social interaction where identity is constructed, and the place of language in this interaction. In the second part we describe the methodology employed for gathering the data. The third part is dedicated to the analysis. We conclude the study with a discussion of some of its implications.

\section{Theoretical background}

\subsection{Constructing identity in social interaction}

The definition of the term identity varies by discipline and approach. Here a constructivist approach is used, as proposed in various studies in discourse analysis (e.g., Benwell \& Stokoe 2006) and sociolinguistics (Bucholtz \& Hall 2005; Lanza \& Svendsen 2007). Following this approach, it is recognized that identities are performed and constructed differently in various narratives: "the practice of narration involves the 'doing' of identity, and because we can tell different stories we can construct different versions of self" (Benwell \& Stokoe 2006: 138). Among the various models of narratives (e.g., Ochs \& Capps 1996), interviews were chosen for this article, seen as one of the types of social interaction (De Fina 2009; De Fina \& Perrino 2011).

Several important factors should be taken into account in analyzing social interaction. First, it is important to consider two different levels of interaction: the macro-level and the micro-level. The macro-level contains sociocultural context, including "larger frames which cannot ignore gender, race, societal organization and cultural pressures conveyed by the external environment" (Lanza 2012: 288). The micro-level concerns "individual features, attitudes, personal perception of the self and the other." (ibid.) In this study, two different countries (Italy and Norway) where interviews were conducted constitute two different sociocultural contexts. It is argued that this macro-level is important for the reconstruction of a new identity. The micro-level is constituted by the individual features of the informants. An effort has been made to partly "neutralize" the differences between the informants: several important unifying criteria were established and applied to selecting the study participants.

Second, the construction of identity takes place in interaction with other people. This is why not only the type of interaction is important for this study, but also the personality of the interviewer and the relationship with the interviewee. "Narratives are tales that tellers and 
listeners map onto telling of personal experience. In this sense, even the most silent of listeners is an author of an emergent narrative" (Ochs \& Capps 1996: 21).

\subsection{The place of language}

Language is often considered a symbol of national belonging. However, in several recent studies the symbolic role of the language is contested, whereas at the same time the role of individual experience, beliefs and attitudes is emphasized: "Whilst it is certainly an oversimplification to treat certain languages as 'symbols' or 'carriers' of 'identity', we are obliged to take account of what people believe about their languages, to listen to how they make use of their available linguistic resources, and to consider the effects of their language use - even where we believe these 'languages' to be inventions" (Blackledge \& Creese 2008: 535-536).

Several studies have shown that for some people "a 'language' held powerful connotations in terms of their sense of belonging and selfhood" (May 2005, cited in Blackledge \& Creese 2008: 535). At the same time, for other scholars the link between language and identity does not have a symbolic connotation and other factors seem to be more important in the reconstruction of a new identity; for example, ethnicity and cultural affinities (e.g., Lanza \& Svendsen 2007; Triandafillydou 2010: 599). Various voices of people talking about their new identity in their host country are presented in the following sections. Their answers will show "how they make use of their available linguistic resources," as phrased by Blackledge and Creese (2008).

Language as a tool of communication plays an important role in social interaction, independently of its status for the speaker (as a symbol of national belonging or not): each language offers different tools for speaking about reality (e.g., Kramsch 2000; Pavlenko 2006). Italian was used in all of the interviews. For informants in Italy, this was a foreign language, whereas for informants in Norway it was their native language. Both groups discuss their proficiency in their foreign language with the interviewer (this was one of the main topics of the interviews based on the study by Norton 2000) and emphasize the importance of its acquisition for integration. However, we believe that as far as, a language is a carrier of meaning, the fact that the same language was used for all interviews is a unifying feature for this study that made it possible to obtain comparable data. The responses show not only how a specific language (the native and the acquired language) is perceived by the informants, but also the role it plays in establishing the relationship between the interview participants. 


\section{Methodology}

\subsection{Data collection}

This study uses interviews as its research tool. The advantage of using this tool is that this format made it possible to ask all of the participants the same questions partly planned in advance and to obtain different but comparable answers that represent different points of view.

The data contain 19 semi-structured interviews conducted by one of the authors of this paper. Nine interviews were conducted in Italy with immigrants from various countries, and 10 interviews were conducted with Italians living in Norway. This paper analyzes only 18 interviews because one of the nine interviewees in Italy does not fall within the definition of "fortunate immigrant" used here for the other informants (seen as a case of voluntary and free migration as adult). This informant moved to the country as a child with her parents, who fled from a Latin American dictatorship.

Each interview lasts approximately 40 to 60 minutes of recorded interaction. The interviews were orthographically transcribed by the interviewer.

The following criteria were applied in selecting the informants:

- A partner from the host country (i.e., an Italian in Italy or a Norwegian in Norway); as seen in Tables 1 and 2 (Reasons column), for the majority of informants this was one of the main reasons for moving to the host country;

- More than five years in the host country (Years column);

- A medium-high sociocultural background: all of the informants were university graduates and had a job;

- Belonging to one of four different age groups: 30-40, 40-50, 50-60, or < 60 years old;

- Having children. ${ }^{1}$

The data relevant for this analysis are presented in Tables 1 and 2 .

Table 1. Informants in Norway.

\begin{tabular}{|l|l|l|l|l|l|}
\hline & Sex & Age & Place of origin & Years & Reasons \\
\hline 1 & F & $40-50$ & Northern Italy & 10 & Education (Erasmus) + job $^{2}$ \\
\hline 2 & M & $30-40$ & Southern Italy & 9 & Partner \\
\hline
\end{tabular}

\footnotetext{
${ }^{1}$ This was important because the various goals of our longitudinal study also include an analysis of different strategies in raising bilingual children.

${ }^{2}$ Where multiple reasons are indicated, the informants themselves provided these in this order when they answered the question about the reasons for migration.
} 


\begin{tabular}{|l|l|l|l|l|l|}
\hline 3 & F & $40-50$ & Northern Italy & 11 & Partner \\
\hline 4 & M & $30-40$ & Central Italy & 10 & Education (Erasmus) + partner + job \\
\hline 5 & F & $30-40$ & Northern Italy & 7 & Partner \\
\hline 6 & M & $<60$ & Southern Italy & 36 & Job \\
\hline 7 & F & $<60$ & Central Italy & 50 & Partner \\
\hline 8 & M & $40-50$ & Central Italy & 15 & Job + partner \\
\hline 9 & F & $<60$ & Central Italy & 35 & Partner \\
\hline 10 & F & $30-40$ & Northern Italy & 8 & Partner + job \\
\hline
\end{tabular}

Table 2. Informants in Italy.

\begin{tabular}{|l|l|l|l|l|l|l|}
\hline & Sex & Age & Place of origin & Years & Native language & Reasons \\
\hline 1 & M & $\begin{array}{l}40- \\
50\end{array}$ & South America & 28 & Spanish & Education \\
\hline 2 & M & $\begin{array}{l}30- \\
40\end{array}$ & Algeria & 6 & Arab, Berber & Partner \\
\hline 3 & F & $\begin{array}{l}40- \\
50\end{array}$ & $\begin{array}{l}\text { South America, } \\
\text { Sweden }\end{array}$ & 23 & Spanish & $\begin{array}{l}\text { To discover } \\
\text { Italian culture }\end{array}$ \\
\hline 4 & F & $\begin{array}{l}40- \\
50\end{array}$ & $\begin{array}{l}\text { Yugoslavia } \\
\text { (Serbia) }\end{array}$ & 25 & Serbo-Croatian & Seasonal work + \\
war in Yugoslavia
\end{tabular}

As can be seen from the tables, all of the informants moved to another country for some personal reasons. A partner is indicated as the main (or one of the main) reasons for moving to another country by eight of the ten informants in Norway and half of the informants in Italy; the other reasons for moving were education, a job (often given as one of the reasons, but not the only one), and discovering Italian culture. Based on these 
characteristics, the informants interviewed match to the group that can be called "fortunate immigrants." Before moving to their final host country, all of them lived in countries with some cultural similarities to their final host country, and their political and economic status did not change considerably. None of them lived isolated in a kind of ghetto for immigrants, having contact only with other immigrants, as was the case for some participants in Norton's study (2000).

\subsection{Preparing for the analysis}

The interview questions were divided into three groups. The first group of questions focused on symbols and expectations concerning the destination country, the encounter with the actual society, and the challenges migrants had to face. The second group was concentrated on the relationship with the new language. The third and final part of the interview inquired about the relationship with the native language. This group also included questions about the language transmitted to children.

For this analysis the answers to two questions were chosen. These questions cover two aspects of the process of reconstructing identity in a new society and the place of language in it. The responses to the first question show how the informants feel themselves to be and would like to be seen: How do you answer the question "where are you from?" (Question 1). The responses to the second question illustrate not only how the informants think they are actually seen and why, but also how the language is perceived (as a symbol or not): Do you feel foreign when you speak your own language? ${ }^{3}$ (Question 2). As will be seen, different meanings of the word straniero are also discussed in their answers.

\section{Analysis}

\subsection{Sociocultural context}

At the macro-level, time and space are two important components for this analysis.

1) Time

The informants in this study arrived in their host country in different periods, as shown in Table 3. The majority of informants moved to Italy in the 1990s, whereas the majority of Italians settled in Norway at the beginning of the 2000s.

Table 3. Period of arrival in the host country.

\footnotetext{
${ }^{3}$ These two questions were formulated in Italian as follows: 1. Che cosa rispondi alla domanda 'di dove sei?', 2. Ti senti straniero in qualche occasione? O quando parli la tua lingua?
} 


\begin{tabular}{|l|l|l|}
\hline Period & Informants in Norway $(n)$ & Informants in Italy $(n)$ \\
\hline $1960 \mathrm{~s}$ & 1 & - \\
\hline $1970 \mathrm{~s}$ & - & 1 \\
\hline $1980 \mathrm{~s}$ & 2 & 1 \\
\hline $1990 \mathrm{~s}$ & - & 5 \\
\hline $2000 \mathrm{~s}$ & 7 & 1 \\
\hline
\end{tabular}

The beginning of the 21 st century is characterized by an increasing flow of "fortunate immigrants" moving for personal reasons from one economically and politically stable country to another. This growing number of "fortunate immigrants" is probably one of the reasons for the positive changes in society's attitude towards the use of another language. Moreover, in the same period studies of the positive impact of multilingualism increased and people become more aware of maintaining their language and transmitting it to children. ${ }^{4}$

\section{2) Space}

The interviews took place in two different countries (Italy and Norway), where the attitude towards the language differs considerably. Italy is a clearly monolingual country. Since its unification in the $19^{\text {th }}$ century, Italy has struggled to standardize the Italian language and to introduce it across the entire territory of Italy; the use of dialects in school and on radio and TV was not permitted. Only in the mid-1970s did television broadcasts accept using different regional pronunciations (Bonomi et al. 2003). Norway has a different approach to dialects. Beyond two official national languages used as two written forms (bokmål and nynorsk), various dialects can be used in the spoken language. There is no standard pronunciation: each region is characterized by its own variety, which is also used in official situations and on television (Røyneland 2009). This means that multilingualism is presented in Norway a priori. This fact can explain why speaking another language may evoke different reactions in Italy and in Norway. The story of immigration to the country may be another factor that affects attitudes towards the presence of other languages in the society. This factor will be taken into account in future research, continuation of this study.

\subsection{The relationship between the interview participants}

\footnotetext{
${ }^{4}$ Spatial limitations prevent a discussion here of various considerations by informants regarding how the attitude to multilingualism has changed in society.
} 
Before analyzing the responses, it is important to describe the relationship between the interview participants. As De Fina (2009) states, "the relationship established between the participants tacitly implies that one of the partners is in a position not only to elicit a certain kind of narrative, but also to evaluate it .... Since accounts are told as responses to specific or implied evaluative questions, they are recipient oriented and they are designed to try to answer those questions" (2009: 240).

The interviews were conducted in Italian by the researcher, who is a native speaker of Italian from northern Italy and lives in Italy. A factor of "shared knowledge" should be considered in this case. We believe that in this study, shared knowledge plays an important role in establishing the relationship between the participants during the interview. The factor of shared knowledge can affect different levels of social interaction.

\section{1) Purposes of interaction}

All of the informants were aware of the purpose of the study. Before participating in the interview, all of them signed a consent form on which the aim of the study was described: "The aim is to investigate the role of language and other national symbols in shaping identity."

This awareness made them often explicitly ask the interviewer for confirmation about the supposed accuracy of their answers. Although the interviewer had assured them of her lack of expectations, some of their answers were followed by questions: va bene così?, ho risposto alla domanda?

\section{2) Participants' cultural and linguistic background}

The informants in Norway have Italian as their native language and were educated in Italy; some of them belong to the same age group as the interviewer. This means that both participants in the interview had a similar cultural background and therefore share the same type of "social and cultural meanings" (Kramsch 2000: 9). However, the researcher lived in Italy and spent only one month in Norway conducting the interviews, and so she did not have the same experience in their new country. Therefore the informants were trying to construct their identity in front of a person from their country of origin, who shares similar cultural concepts with them, but did not know their host country like they do. One informant even commented on these differences:

(1) ... è molto importante poter comunicare con persone che sono sulla tua stessa lunghezza d'onda, che hanno la tua stessa cultura che provengono dal tuo stesso 
paese e che hanno i tuoi stessi interessi e le tue stesse esperienze di vita perché anche loro abitano qui in Norvegia. (2n)

The informants in Italy do not have Italian as their native language and do not share the same cultural code transmitted by the language. "Foreign language learners, who have not grown up in the community that speaks the language, have much greater difficulty identifying the range of potential meanings available in that speech community" (Kramsch 2000: 25). At the same time, they had been living in Italy for many years, are proficient speakers of Italian (despite some of them complaining that they miss some nuances of the language) ${ }^{5}$ and they share with the interviewer the same knowledge about the contemporary situation in Italy. This shared knowledge is often emphasized in the interviews, especially when discussing the problems of Italy with the interviewer:

(2) Sai che Trieste è una città abbastanza triestinissima, cioè molto nazionalista che in certi momenti esce in superficie e c'erano percepivo i discorsi proprio fascisti al momento quando arrivavo a Trieste. (16i)

(3) In Alto Adige mi hanno detto sì meglio straniera che del sud dell'Italia e lì ho sentito per la prima volta questa parola "terrone". (14i)

(4) vieni vista un po' come diversa perché come mai tu sei arrivata da un paese così devi essere come loro o anche stare un po' sotto di loro. Questo in Italia è una tragedia, veramente. (14i)

This knowledge about modern society in Italy is often missing to the informants from Norway, as one of the informants says: non ti senti più completamente italiano perché ormai ti sei staccato da quella realtà.

The interviewer shared a different kind of knowledge with both groups of informants. Through this knowledge, both groups considered her not to be an outsider, but part of a group. We believe that the interaction during the interview was based on the shared knowledge between the participants, and in the process of reconstructing their identity the informants took into account this shared knowledge they had with the interviewer. This may be one reason why Italy was always in the focus of the responses: as shown in the following sections, the Italians in Norway emphasized their cultural belonging to Italy, whereas informants in Norway pointed out their strong link to Italy and stressed the time they spent there.

\footnotetext{
${ }^{5}$ Some informants made some small errors that were left in the quotations in the analysis.
} 
(5) io sono nata là quindi questo è importantissimo e mi appartiene completamente, ma ormai sono più anni qua che là della mia vita capito, dico questo, sono più di qua che di là, dimmi tu da dove sono.(18i)

\section{3 "Where are you from?" Answers to Question 1}

The responses to this question show the place of the country of origin and host country in reconstructing identity.

\subsubsection{Belonging}

Independently of their length of stay in Norway, all of the Italian informants immediately identify themselves as Italians. Some of them add their city of origin followed by information about the city $(6,7)$. Some informants use intensifiers (e.g., certo, senz'altro in (8), or al 100\% in (9)), as through the question about belonging places the fact of belonging as such in doubt.

(6) ehhh beh prima di tutto rispondo che sono italiano ovviamente se vedono semplicemente che sono straniero la prima cosa che mi dicono ah italiano ma di dove? Di Roma, perché ovviamente quasi tutti i norvegesi che si rispettino sono stati in vacanza in Italia. $(4 \mathrm{n})$

(7) no beh sicuramente Italia, rispondo Italia e poi eventualmente Verona Mantova, non tutti conoscono Mantova dico Verona sono molto fiera di essere italiana ... $(5 n)$

(8) io sono italiano, sì sì, ma certo, senz'altro. (2n)

(9) torino subito (...) no no io sono al $100 \%$ italiana . . . non andrò mai a dire sono di Oslo o sono mezza norvegese, non ci penso neanche sono di Torino sono italiana proprio. (10n)

The participants in Italy answering the same question often do not provide a clear unique answer, but discuss their belonging with the interviewer. For example, two informants answer that sometimes they say that they belong to their small town in Italy.

(10) Io gioco sempre un po' con questo a volte trentina, a volte ecuatoriana ... io sono nata là quindi questo è importantissimo e mi appartiene completamente, ma ormai sono più anni qua che là della mia vita... (18i)

(11) a volte dico "punt lamber", lo dico per provocazione, mi viene da dire da ponte lambro in dialetto, che io sono di ponte lambro. La gente chiede sempre di dove sei, allora ho capito che vogliono sapere da che paese sono originario. (15i) 
Another, even though she names her country of belonging in the answer, emphasizes the importance of the time dimension: sono qua da una vita.

(12) io rispondo che sono nata in Argentina e cresciuta in Svezia e che sono qua da una vita. (13i)

Two informants from the former Yugoslavia explain in detail different levels of their belonging: a country (that does not exist), region or city. The time opposition of before versus now is very marked in their answers:

(13) quando sono arrivata e dicevo dalla Serbia non sapevano neanche dove è. Allora dicevo ex Jugoslavia e conoscevano. Dopo e durante la guerra volevano precisare la nazione ... Interviewer: e oggi? Oggi ho la cittadinanza ${ }^{6}$ doppia italiana e slava. ... Quando mi chiedono oggi io sono fiera di dire che sono della Jugoslavia unita. (14i)

(14) io generalmente già prima che la Jugoslavia sparisse dicevo sono di Zagabria, e uno doveva pensare dove metterla, poi naturalmente dicevo che sono Jugoslava perché questo era il contesto più ampio. (16i)

One informant immediately rejects the possibility of feeling herself to be Italian, but she also emphasizes that she is no longer from her country of origin:

(15) eh sì perché non mi sento italiana per niente, sono cinese ma non sono cinese di mia patria, mi sento cinese d'altro mare sempre, ... solo non mi sento da nessuna parte, allora, sono cinese residente in Italia. (17i)

Only two informants in Italy identify themselves immediately with their place of origin:

(16) io rispondo subito sono argentino di Buenos Aires. (11i)

(17) quando mi dicono di dove sei io dico sono algerino. (12i)

\subsubsection{The image of the country of origin}

The interlocutor's knowledge about the country of origin comes out in several answers on belonging. In Norway, the informants emphasize the fact that Italy is a well-known country. In Norway everybody knows something about Italy, and this is why it is easy to declare one's belonging to that country. Some informants focus their answers on Italy's

\footnotetext{
${ }^{6}$ Interestingly, only two informants mention their current citizenship: one in Italy (ex.13) and one in Norway, saying: "Io, sono sempre cittadino italiano anche se, se volessi, da domani potrei diventare cittadino norvegese, ma non riesco ad immaginare il nome con la cittadinanza norvegese, non è associato"
} 
positive image in Norway and some of them admit that it should be more difficult for immigrants from other countries.

(18) l'Italia è amata da tutti, risulta sempre che tutti sono stati a Firenze, a Milano. $(8 n)$

(19) loro adorano ascoltare l'italiano, lo reputano una lingua bellissima quindi io sono proprio orgogliosa. (1n)

(20) sono fortunato venendo da un paese che in un certo senso è considerato positivo in molti modi quindi magari polacchi o asiatici o comunque del medio oriente non sono forse trattati nello stesso modo. (4n)

At the same time, Italians in Norway are also aware that the image of Italy is usually not only positive. One informant compares the different attitudes towards Europeans from different countries, establishing a sort of hierarchy among them:

(21) ma ad esempio c'è differenza anche tra un italiano e un olandese, tra un italiano e un tedesco, tra un italiano e un inglese o tra un italiano e un americano. Il Nord Europa in genere ha una certa visione del sud Europa, tu lo sai quindi magari sono stereotipi, cliché, ma c'è molta verità in questi stereotipi . (2n)

Another informant also mentions negative images that can be related to Italy:

(22) ci sono delle persone che si riferiscono all'Italia soltanto per luoghi comuni che sono estremamente negativi. (9n)

(23) ... devo dire sempre più ormai c'è anche coscienza dei grossi problemi italiani, e non solo diciamo quegli stereotipi ma anche diciamo il problema del degrado ambientale. (9n)

The situation with the informants in Italy is different. Some of them admit that their interlocutors often do not know anything about their country:

(24) Invece qui in Italia rimango sempre lo straniero e a parte che quando dico che sono del Togo non lo sa nessuno dove è il Togo perché qui ci sono molti problemi. (15i)

One of the informants from the former Yugoslavia explains that people became more interested in her belonging during the war in Yugoslavia (see example (12) above). The others do not even mention the image of their country of origin.

\subsubsection{Becoming closer to the host country}

All informants in both countries agree on the importance of acquiring the language to help them integrate better into the new society. Moreover, all of them admit that there are 
some other acquired elements that bring them closer to the people of the host country. Among these elements, Italians in Norway mention behavior and the attitude to the surrounding world:

(25) Sono molto fiera di essere italiana però sì ammetto che una parte di me è molto contenta di queste, forse per come sono fatta io, della rigidità norvegese, dell'efficienza, mi sento di adattarmi bene a questa nuova realtà, in quel senso mi sono norvegesizzata. $(5 n)$

(26) Quando io vengo in Italia io vengo considerata quasi straniera perché gli amici dicono ma tu sei così calma, così nordica, sei così, qui dicono che sono un vulcano $\ldots(7 n)$

In Italy, nobody cites changes in behavior. Among the acquired elements, an Italian accent in native language is mentioned and the fact of living in Italy for a long time.

(27) ma allo stesso modo si sente quando vado in Argentina. Adesso che ho preso l'accento, c'ho un accento italiano. (11i)

(28) La cosa strana è che in Togo quando parlo con i miei cugini e loro mi dicono eh l'italiano, mi chiamano l'italiano. (15i)

\section{4 "Do you feel foreign when you speak your own language?" Answers to Question 2}

The responses to this question can be divided into two groups: 1) a negative answer (e.g., $m a$ il fatto del sentirsi straniero associato a una lingua non è una cosa che mi appartiene no), and 2) a positive answer in which the discussion about the word straniero comes to the fore. Two main tendencies can be distinguished in this discussion: 1) one group of informants accepts being foreigners and explains why they feel themselves to be foreigners, and 2) another group of informants discusses the meaning of the word straniero.

\subsubsection{Reasons for being a foreigner}

There are two responses given in Norway in which the informants try to explain the reasons for this status.

(29) beh uno è sempre straniero immigrato comunque, non te la fanno passare liscia così facilmente. Interviewer: in che senso?- Nel senso che è chiaro dal modo in cui si parla, dagli argomenti che si affrontano che in un certo senso cercano sempre di non farti pesare il fatto di non essere norvegese. $(4 n)$

This informant explains that, for him, the status of "being a foreigner" is connected to the way one talks and to the topics in the conversation, but not to the use of another language as such. 
It is worth mentioning that this informant generalizes his point of view: he does not use the first person in his answer, but an impersonal construction: uno è sempre straniero.

The same person also discusses the definition of the status "not being Norwegian" and introduces also the idea of "being in between": senti di non appartenere né all'uno né all'altro. ${ }^{7}$

(30) Poi più si va avanti più ci si integra quindi si sente un po' di meno la cosa però in un modo o nell'altro viene sempre fuori insomma il discorso che comunque uno non è norvegese, non in maniera negativa necessariamente, semplicemente come uno spunto di discussione però ci si sente sempre un po' estranei, sì alla fine la persona che emigra all'estero è un apolide non ti senti più completamente italiano perché ormai ti sei staccato da quella realtà e non sei più parte del processo che comunque va avanti senza di te e quando torni a casa ti senti un po' un estraneo ma allo stesso tempo non diventerai mai norvegese indipendentemente da quanto tempo vivrai qui avrai le tue radici italiane, quindi sei un po' in un limbo in mezzo, che dà sia libertà in un certo senso, apertura mentale ecc ma ovviamente è anche un po' pesante perché senti di non appartenere né all'uno né all'altro. (4n)

It is worth mentioning that in the example (30), the mitigation $u n p^{\prime}$ ' is used with the term estraneo in both cases. It should also be pointed out that in this example the position described as "in between," despite the difficulties mentioned, is characterized in a positive way as libertà and apertura mentale.

In another response in which the reasons for being a foreigner are explained, the informant declares her national belonging: la mia identità è legata al mio paese, and also mentions external differences (ho anche un aspetto molto italiano) but does not see any problem in that:

(31) io sono in realtà sempre una straniera, perché io sono italiana, ho anche un aspetto molto italiano quindi non scivolo diciamo nel panorama norvegese non mi ha mai creato problemi, come ripeto perché la mia identità è in realtà legata al mio paese, all'Italia e quindi non mi ha creato problemi . . . (9n)

In Norway, only two informants answer this question by accepting the term straniero without any discussion and explaining the reasons for it, whereas in Italy more informants admit to feeling themselves to be foreigners; language is one of the most frequent reasons.

\footnotetext{
${ }^{7}$ Many informants in Norway and in Italy mention the same feeling in different ways; for example, "sono cinese ma non sono cinese di mia patria, mi sento cinese d'altro mare sempre".
} 
(32) che domanda difficile. Se parlo la mia lingua madre ovviamente mi sento straniero, estraneo al posto, giusto? Se parlo nella lingua italiana, come dire, magari boh se dico qualcosa pronunciato malissimo può capitare che io mi senta estraneo, è difficile questa domanda perché non mi pongo il problema. (12i)

One informant connects it to situations when he speaks his native language:

(33) più che altro parlando la mia lingua madre con i compaesani lo avverto che per la gente ti isola, praticamente, anche perché lo vedo anche di riflesso anche io, se salgo sul treno adesso e vedo gli stranieri che parlano tra di loro, avverto che sono stranieri, è ovvio, la lingua ti estranea anche perché poi se uno non capisce quello che l'altro dice, interpreta. (15i)

In their responses to the same question, other informants often discuss their proficiency in Italian (not perfect for them): ${ }^{8}$

(34) parlo italiano ma sempre straniera. (17i)

(35) sì si perché a volte anche se l'italiano, ormai appunto sono 26 anni che sono qua, qualche volta ancora non è proprio del mio completo, mi piacerebbe, mi manca qualche sfumatura. (18i)

(36) Ero un po' felice e orgogliosa di averlo imparato bene e di esprimermi bene perché questa era la mia preoccupazione, di parlare come nella mia madrelingua, però più uno era attaccato e più il vocabolario è più vasto e ricco è più difficile esprimersi nella lingua straniera tale e quale nella madrelingua. (14i)

Some Italians in Norway also mention their competence in Norwegian, especially at the beginning of their stay in Norway (time is explicit in their comments), but their comments concentrate more on the use of Italian and the focus is on the positive perception of it in the Norwegian society.

(37) Sì forse più all'inizio perché magari mi spiegavo anche male, però devo dire che se parlo italiano con i miei figli e intorno a noi ci sono norvegesi ricevo sorrisi devo dire la verità, sì. (3n)

(38) In parte mi piace parlare italiano ai norvegesi, alcune volte ho anche avuto delle risposte in italiano. (5n)

(39) allora per quanto riguarda l'italiano non credo che ci siano problemi, non ho mai almeno non ho mai avuto sensazioni che reagissero al fatto che io parlassi italiano. $(9 \mathrm{n})$

\footnotetext{
${ }^{8}$ The terms and examples used to describe language proficiency in the foreign language should be a topic of another analysis.
} 


\subsubsection{The meaning of the word straniero}

In another group of responses to the same question (given mostly in Norway), the term straniero is accepted, but the focus is on its positive connotation. A contrastive phrase usually used in this case shows that the word straniero a priori has a negative connotation for the informants, and that is why they try to point out its positive connotation.

(40) quando parlo in norvegese immagino che loro capiscano abbastanza in fretta che io non lo sono, quindi è un presupposto, parto dal presupposto che io sono straniera ma non lo vivo con disagio, assolutamente. (1n)

(41) non mi sento estranea o straniera in senso negativo. (10n)

Interestingly, the word diverso or the idea of "being different" often emerges in these explanations of the word straniero:

(42) io l'identità dico mi sono sempre sentita diversa però con un segno positivo. Interviewer: anche per la lingua? - Beh inizialmente ovvio quando imparavo era difficile, però non avevo la percezione dell'essere diversa in questo senso, avevo la percezione di essere una persona che non parlava la lingua e quindi dovevo impararla. (7n)

(43) no quando parlo il norvegese diciamo estranea perché ho l'accento, lo so benissimo, . . . però parlare italiano . . . non mi interessa cosa pensano gli altri anzi anche se mi dicono "stai zitta che urli" che ne so io me ne frego. (10n)

In Italy, only one informant introduces the same idea of being "different" in a positive sense when answering the same question "Do you feel foreigner?":

(44) c'è comunque un piacere del sfoggiare una diversità che comunque dà secondo me anche nel mio caso a volte anche uno status symbol. Se io sono in Italia e parlo svedese non è come ecco parlare un'altra lingua oppure se sono in Svezia e parlo italiano, diciamo che questa diversità perché io ci ho lavorato su questo non mi fa soffrire e mi fa sentire comunque bene, è una ricchezza per me. (13i)

Interestingly, this informant introduces also the expression "status symbol".

In other responses, the fact of being different is interpreted in a negative way, as a criterion that excludes a person from a group.

(45) Invece quando sei nella vita normale con le persone di un medio-basso livello, così chiamiamolo, vieni vista un po' come diversa perché come mai tu sei arrivata da un paese così devi essere come loro o anche stare un po’ sotto di loro. (14i) 


\section{Discussion and conclusion}

The starting point of this study was the idea that despite the fact that language is often seen as a symbol of national belonging, its status is not stable but varies depending on many other factors. The status of language changes for each individual and can depend also on the sociocultural context in which the individual lives. Moreover, its place can be described differently when the identity is (re)constructed in social interaction, as Benwell \& Stokoe states: "because we can tell different stories we can construct different versions of self" (2006: 138).

To describe this different status of the language, this paper presented a comparative analysis of some parts of 18 interviews conducted with two groups of immigrants living in two different sociocultural contexts and answering to the questions of the same interviewer, native speaker of Italian, living in Italy.

As far as the process of (re)constructing identity takes place "here-and-now" in the communication process in interaction with other participants, the sociocultural context as well as the relationship between the participants and the language of communication affect the responses about the place given to the language in this process. Both groups of informants shared two different types of knowledge with their interlocutor (interviewer from Italy) and tried to establish a relationship of complicity based on this shared knowledge. In this context, the feeling of "being excluded" for certain reasons often emerged in Italy, whereas in Norway the idea of "being different" in a positive sense is introduced in several responses. This idea is intended to convey more distinctive features that can characterize a person but do not exclude him or her from society.

The data analysed shows that Italians in Norway seem to be more attached to their national belonging; they immediately identify themselves as Italians when answering the question "where are you from". They do not feel themselves to be foreigners when using Italian and do not see this as a factor that marks their exclusion from the group. Moreover, they positively interpret the word straniero and point to diversity as one of the components of its meaning. Two explanations can be given to this interpretation. The first explanation involves the micro-level of the social interaction: Italians talking to an Italian interviewer try to underline their link to Italy and the positive sides of living in Norway. They show to a guest their new home and want to create a positive impression of it. The second explanation can be situated on the macro-level, including the cultural and external environment: Norwegian society that proposes immigrant integration programs and have several policies prioritizing 
immigrants may be seen as a more opened and "inclusive" society. However, this observation should be investigated in the future based on the other type of data.

The responses in Italy showed that several informants are less convinced (than Italians) about their national belonging. They discuss their status of being "in between" two countries, and they emphasize their strong connection to Italy, first of all in terms of time (e.g., sono qua da una vita). For quite a few of them, language is an important factor with a twofold role. On the one hand, their proficiency in Italian (often discussed with the interviewer, a native speaker of Italian) shows their belonging to Italy. At the same time, some nuances, mistakes, or an accent can make them feel foreign and excluded from society. The language they use (both native and Italian language) is often connected to the idea of "being foreigners" for them.

Thus, the role of the language varies not only for different individuals, but also in different societies. Language becomes a sociocultural factor in identity building and assumes different statuses. It seems that in a multilingual society where no standard language is imposed, another language is seen as part of diversity; it is a feature that can characterize a person. In some responses in Italy as well, it emerged that it is easier to be a foreigner in regions where another language is always present — such as Alto Adige, where German is also considered an official language. At the same time, in a monolingual society where the idea of a standard language is promoted, the use of another language carries speakers outside the standard and excludes them from the group.

If language is seen as an element that can differentiate people in the sense of "excluding" them, this means that it can also be considered a symbol of belonging that associates a person with a group. If language is seen as one of many individual features of a person, then its main function does not consist of including or excluding a person in relation to a group. In this case, language does not have a symbolic role; it is not a symbol of belonging, but simply one feature among other features characterizing diversity. A set of features is free, and any one of them has a strictly defined function or connotation. For people that accept this vision, many different features contribute to shaping an individual's diversity. The language, in this case, can be interpreted as a symbol of diversity. These two different statuses of the language can have different implications for promoting the multilingualism in society and in family.

\section{References}


Benwell B. and Stokoe, E. 2006. Discourse and Identity. Edinburgh: Edinburgh University Press.

Blackledge, A. and Creese, A. 2008. 'Contesting 'Language' as 'Heritage': Negotiation of Identities in Late Modernity." Applied Linguistics, Vol.29(4): 533-554.

Bonomi I., Masini A., Morgana S. (a cura di), 2003. La lingua italiana e i mass media. Carocci.

Bucholtz, M. and K. Hall. 2005. "Identity and Interaction: a Sociocultural Linguistic Approach.” Discourse Studies, 7 (4-5): 585-614

De Fina, A. 2009. "Narratives in Interview. The Case of Accounts. For an Interactional Approach to Narrative Genres." Narrative Inquiry, 19 (2): 233-258

De Fina, A. and S. Perrino. 2011. "Introduction: Interviews vs. 'Natural' Contexts: A False Dilemma." Language in Society, 40: 1-11.

Golden, A. and Lanza, E. 2013. "Metaphors of Culture: Identity Construction in Migrants' Narrative Discourse." Intercultural Pragmatics, 10 (2): 295-314

Kramsch, C. 2000. Context and culture in language teaching. Oxford University Press.

Lanza, E. 2012. "Empowering a Migrant Identity: Agency in Narratives of a Work Experience in Norway." Sociolinguistic Studies, 6 (2): 285-307

Lanza, E. and Svendsen, B. 2007. "Tell me who your Friends are and I might be able to tell you what Language(s) you speak: Social Network Analysis and Multilingualism.” International Journal of Bilingualism, 11: 275-300.

Lindenfeld, J. and Varro, G. 2008. "Language maintenance among "fortunate immigrants": The French in the United States and Americans in France." International Journal of the Sociology of Language, Vol. 2008(189): 115-131.

Norton, B. 2000. Identity and Language learning. Multilingual Matters

Ochs, E. and Capps, L. 1996. "Narrating the Self". Annual Review of Anthropology, Vol.25: $19-43$

Pavlenko, A. 2006. (ed.) Bilingual minds: emotional experience, expression, and representation. Clevedon, UK: Multilingual Matters.

Røyneland, U. 2009. "Dialects in Norway: catching up with the rest of Europe?" International Journal of the Sociology of Language: 196/197: 7- 31 .

Triandafyllidou, A. 1998. "National Identity and the 'Other'." Ethnic and Racial Studies, 21 (4): 593-612 